\title{
The Perception of Community Radio as Public Sphere and its Potential Impact on Political Action: Lessons from Tanzania
}

Adeniyi K. Bello, Department of Communication, Media, and Journalism, University of North Georgia, USA. Email: akbello@ung.edu E

Kent Wilkinson, Regent Professor of International and Hispanic Communication, College of Media $\mathcal{E}$ Communication, Texas Tech University, Lubbock, Texas, USA. Email: kent.wilkinson@ttu.edu

\begin{abstract}
This study takes initial look at the promise of community radio as a public sphere. Given the interest that community radio has generated in the communication for development (C4d) arena, particularly its portrayal as a tool for democracy and good governance, the study attempts to ascertain whether the model through its flagship genre - political talk-back program can enact political participation or engender political efficacy within the African context. Data for the study came from a field research conducted in the United Republic of Tanzania. The study combines a survey with focus group and in-depth interviews. Relationships between engagement with community radio, political participation and interest, and political efficacy were examined, as well as its association with individual's level of interpersonal discussion of local issues. A key finding shows that involvement with political talk programs on community radio can promote political participation and interest. Similarly, the result reveals an association between participation on talk program and political efficacy. These results are encouraging in that they point to community radio as serving useful democratic purpose in empowering citizens by giving voice to those considered "marginalized", and at the same time fulfilling a major role of providing valued information at the local levels. As the foundation of public sphere, the stations seem to encourage active citizen participation and a healthy diversity of opinion. Certainly, this form of communication is needed for the occurrence of sustainable democratic development.
\end{abstract}

Key Words: community radio, public sphere, political efficacy, political awareness, Tanzania

To cite this article: Bello, A.K \& Wilkinson, K. (2017). The Perception of Community Radio as Public Sphere and its Potential Impact on Political Action: Lessons from Tanzania. Journal of Development and Communication Studies, 5(1): 22- 43. https://dx.doi.org/10.4314/jdcs.v5i1.2 


\section{Introduction}

The media in sub-Saharan Africa have failed in facilitating public debate or in underpinning democracy since the late 1950s and early 1960s when most of the countries in the region gained their political independence. Particularly, the region's plethora of broadcasting systems operate under restrictive laws regarding public access and ownership structures that makes them less useful for contributing to the democratic ideals of popular participation. Access to information that helps citizens to make informed democratic choices was limited. Broadcasting was monopolized under the pretext that it is a public service critical to development, fostering of unity, and promotion of national culture and identity (Article XIX, 2003). In effect, the media's traditional "watchdog" role which ensures that elected representatives uphold their oaths of office and carry out the wishes of those who elected them are severely restricted.

However, a dramatic shift in ownership structure from government to private and community control began in the early1990s. A BBC World Service Trust (2006) study shows the number of community radio stations operating in the region rose by over $1,000 \%$ between 2000 and 2006, while commercial radio grew by an average of $360 \%$ during the same period. This phenomenal growth was attributed to the 1990s-popular global political democratization process, accompanied by the liberalization of the media environment, helped by technological advances which facilitated installation and operation of small radio units, even in the region's most remote areas (Panos Institute West Africa, 2011). A central question that remains unanswered however is, whether small-scale community radio can produce an appreciable civic outcome in a globalized world dominated by larger media. This study investigates this and related questions within the contemporary context of African communities.

The purpose of this study is to explore the promise of community radio as public sphere. Specifically, this study examines whether community radio can catalyze political action (i.e. political participation and efficacy) that can lead to social change in Africa. This follows the argument that political efficacy and participation are important behaviours for a healthy democracy. Abramson and Aldrich (1982) described political efficacy as a determinant of political behaviour, stating that without one feeling capable and having the belief that one's actions are consequential, one has little incentive to participate in public discourse. Thus, the media's role in stimulating political participation is important because levels of engagement in a democratic system have consequences for the system's parallel equity and legitimacy (Rosenstone \& Hansen, 1993).

\section{Rationale and Context}

The defining characteristics of community radio are, as Barlow (1988) states, "their non-commercial status as broadcast outlets, their 
avowed policy of local community involvement in their programming, and the democratic organization of their institutional procedures and practices" (p. 81). As a non-commercial media, community radio's audience is not in the ordinary sense of casual listeners, but rather, actual broadcasters and producers, actively engaged in managing and planning of a local communication project (Gaynor \& O'Brien, 2011). Unlike public radio, community station changes the relationship that exists between it and its listener by creating real possibility of a collective control over the means of mass communication to those to whom it had been denied. In Carpenter's (2011) view, providing public access to the medium "infers ability to come closer to communication systems" (p. 91). Thus, given this unique offer of public access, community radio is viewed as a tool for increasing listeners' sense of personal power and community power (Fairchild, 2001).

To this extent, policy development experts within bilateral and multilateral organizations considered the potential role of the model in ensuring good governance and transparency in decision-making and thus, accorded it high priority as a major platform of development (Deane, 2005). To the experts, the creation of free, diverse, and pluralistic media is a strategic approach for eradicating poverty and promoting popular democracy. For example, Sen (2001) argues that democratic governance is not sustainable without development because at the heart of how democratic governance contributes to development is the right to freedom of expression. Also, critical communication scholars view community radio as the new "public sphere" that offers space for citizens to come together to articulate their autonomous views, and to influence the political institutions of society (Castell, 2008; Tucker, 2013). With potentials to diffuse information and reinforce emotions and beliefs about society, politics and political life, community radio in the subSaharan Africa region is viewed a veritable tool for connecting citizens and their government (Mwesige, 2009; Tettey, 2011).

While previous research on traditional media operating within communities (such as community newspapers and weeklies) have revealed the dynamic relationships that exists between media and community, which fosters political participation and community integration (cf. Berelson, Lazersfeld, \& McPhee, 1954; Lazersfeld, Berelson, \& Gaudet, 1944; McLeod, et al., 1996; Stamm, 1985; Viswanath, Finnegan, Rooney, \& Potter, 1990), we have yet to fully understand the role of community radio as a communication variable in local political processes. Although due to its unique format and potential as public sphere, research interest on community radio have also grown during the past few decades (cf. Forde, Foxwell, \& Meadows, 2002; Gaynor \& O'Brien, 2010; Jankowski, Prehn, \& Stappers, 1992; Meadows, Forde, Ewart, \& Foxwell, 2005). Yet, the bulk of the literature on community radio in Africa focuses on sponsored development projects which begin with a social goal in mind (and with special one-time funding), all too 
often relying on anecdotal evidence or case studies (cf. Da Costa, 2012; Jallov 2007). Jankowski (2003) notes that the lack of empirical studies of the use and effects of community radio is especially problematic, in that case studies typically contribute only incrementally to our theoretical understanding and model building of the medium. The problem with sponsored policy studies generally is that seldom can they be expected to rise above the basic mandate of delivering data that are deemed functional for assessing the restrictive policy parameters (such as the degree of media use and relation to station activities to overall objective) set by the donors or policy objectives of state, if sponsored internally.

While such reports do offer contributions, researchers' association with policy institutions makes it difficult to determine whether the investigations are conceptually driven and ultimately contribute to a theoretical understanding of community radio's place in society. As such, it can be argued that we lack anything close to the comprehensive knowledge of community radio operations in Africa. This study addresses this gap in the literature specifically by examining the role of community radio as a public sphere and its contribution to citizens' political participation and efficacy in Africa.

Community radio has a short history globally, but its emergence is considered a blessing to countries like Tanzania. With an estimated current population of 44.9 million (World Population Review, 2012) about $88 \%$ of Tanzanians live in rural communities where only about $5.3 \%$ of the population have access to electricity. Until recently, Tanzania's state-run radio network (RTD) was the only medium promoting awareness of development and social issues in rural areas. Given the country's geographic size--Tanzania is three times the size of the U.S. state of New Mexico--and terrain (32 mountain summits - the highest being Mt. Kilimanjaro at 19,340 feet [5895] meters), it is prohibitively expensive to distribute radio signals to some remote areas (Intermedia, 2011). About 27\% of Tanzanian households have television, while $41 \%$ of the population watches weekly. Still, radio remains the dominant broadcast medium.

Newspapers rank at the bottom of news and information sources used regularly by Tanzanians, mainly due to poor circulation (Intermedia, 2011). Thus, a crucial information gap exists due to the lack of radio stations in regional languages. Recently, UNESCO has helped set up community stations in Tanzania and across Africa, and the international organization is providing capacity building assistance to the stations to increase civic participation and gender-responsive communication for sustainable development. Currently, Tanzania has 28 registered community radio stations located in rural communities with an average 16 million listeners weekly. The changing media landscape brought about by the licensing of community and private broadcasting outlets operating side-by-side, makes the country a wellsuited site for this project. This study was undertaken as the lead 
author's dissertation project conducted in the United Republic of Tanzania between April and June 2015.

\section{The Public Sphere and Community Radio}

The concept of public sphere was first defined and outlined by the German philosopher, Jürgen Habermas in The Structural Transformation of the Public Sphere (1962/1989) where he links the media and democratic community formations in discussing a deliberative model of democratic society, one where communication is central to maintaining and sustaining good governance. Habermas introduced the public sphere as:

A sphere which mediates between society and the state, in which the public organizes itself as the bearer of public opinion, accords with the principle of the public sphere that principle of public information which once had to be fought for against the arcane policies of monarchies and which since that time has made possible the democratic control of state activities. (Habermas, 1974, p. 50)

The two major themes in Habermas' book include an analysis of the historical genesis of the bourgeois public sphere, and an account of the structural change of public sphere in the contemporary era with the rise of state capitalism, the culture industries, and the increasingly powerful positions of big business in public life. Habermas provided an historical analysis under which the public sphere emerged and grew as an independent arena of public debate and discussion, focusing upon European bourgeois political life of the 17th through the mid-20th centuries, specific to the societal conditions of Germany, Britain, and France (Calhoun, 1992; Dahlgren, 1995; Kellner, 2000).

In his historical recounting, Habermas developed a critique of bourgeois society showing its internal tensions and the factors that led to its transformation and partial extinction, as well as the emancipatory potential that it encompassed despite its ideological misrepresentation and contradictions (Calhoun, 1992). Habermas states that the sphere developed as the public space between government and the society, an independent forum where individuals participate in the making, exchange, and mobilization of political opinion. According to Habermas, the sphere was separate from the state and the official economy; its participants gather to discuss matters of common interest, to criticize the state, and to hold the state accountable to the citizenry. In ideal terms, the sphere is the realm of social life where information and views on questions of common concern are exchanged, leading to the formation of public opinion. Dahlgren (1995) asserts that "the public sphere takes place when citizens, expressing the rights of assembly and association gather as public bodies to discuss issues of the day, specifically those of political concern" (1995, p. 7). From a sociological perspective, Calhoun 
(1992) suggests that the public sphere's value lies in "its potential as a mode of societal integration" (p. 6).

Further, Habermas argues that the evolution of the public sphere made it for public opinion to act as a counterweight to state power and the powerful interests that shaped bourgeois society. He further elaborated that the classical bourgeois public sphere was constituted around rational critical arguments, in which the merits of ideas, and not the identities of participants, were crucial. To summarize, the public sphere was conceived as a forum where people meet as co-equals and engage in public issue debates in a rational-critical fashion, then guide state actions. Thus, the public sphere was a communicative fulcrum within which the bourgeois learned to constitute themselves into a counter hegemonic force and generate collective (public) power. Hence, individuals and groups acquired new power to shape public opinion, giving direct expression to their needs and interests while influencing political practice. Louw (2001) suggests that "at heart, the public sphere issue seems to be about creating alternatives to one dimensional, narrowed, manipulated, or closed communication" (p. 101). In other words, the public sphere is the arena for diverse opinion.

Although the notion of public sphere is normative, the concept relates centrally to citizens' involvement with politics. Most importantly, its unique features of free expression, openness, access, and participatory debate of issues are closely linked to the principles and ethos of community radio. Tucker (2013) argues that community radio produces community involvement that enables "collective capacity" to act as a bulwark against government and corporate power, and it can mobilize citizens around common problems by serving as a forum for developing solutions. As an alternative to the mainstream media, community radio can re-invigorate the public sphere by reflecting local cultures (Meadows et al., 2005), and stimulating debate and discussions. Fairchild (2001) argues that community radio has tremendous potential to help its participants realize their democratic goals in a variety of contexts and locales. Unlike public radio, it serves specific communities with individuals whose issues are in alignment. In other words, community communication is not just about people in general, but it is about individuals in specific (local, ethnic, religious, culture) contexts (Hollander, 2002). As explained by Day (2009), the listener, through the process of engagement with the station may become empowered and in turn empowers and enhances the community. People listen or are involved with the medium because of shared interests. As Hollander (2002) writes, it is an existing relationship among citizens in the community that attracts them to relevant issues presented by community media, "not politics in general; but local politics, not national sports but local sports; not crime in general but crime in the community" (p. 33).

The democratic decision-making built into the organizational structures of a community radio encourages active engagement and a 
healthy diversity of opinion. Audiences across all community models express a strong appeal to identify with their local stations because of their openness and inclusiveness. Downing (2001) likened community radio operation to working through horizontal social channels. Such horizontal sharing makes possible collective problem identification and solution. In this way, community radio could play an important cultural role by encouraging dialogue between diverse components of a community. Barlow (1988) suggests that the model's democratic structure encourages "active citizen participation and a healthy diversity of opinions" (p. 81). The emancipatory potential of community radio is distinctly present in the communicative process, from creation and production of content to distribution and consumption of programming, each of which accounts for its social and political importance. Day (2009) adds that the main aim of community radio is to stimulate people within the community to work to improve their community by connecting with one another. In short, participation is not an end but a means leading to participation in the broader life of the community. Thus, community radio is viewed as the promotion of good governance and a safeguard against abuse of power that essentially leads towards the ideal of a truly inclusive polity.

Indeed, the popular view of community radio as public sphere emerged from relatively recent innovations in development communications in which advocates have argued for the adoption of a participatory paradigm for media development projects in poorer countries and communities (Ascroft \& Masilela, 1994; Melkote, 2002; Servaes \& Malikhao, 2008). From this perspective, community radio outlets are issue-based organizations devoted to counteracting existing distribution of power by facilitating coalitions among other issue-based organizations and providing citizens a platform for airing their views. This perspective assumes that if a station can motivate and train numerous volunteers to produce radio programs, a large pool of engaged listeners could become involved, resulting in successful community service. This argument presupposes that participation in the station could serve as a bridge to participation in society, or that access to information could lead to access to a larger polity and a steady amplification of social voice. Thus, community radio initiatives - with its call-in political talk program - are cast as movements for social change and democratization, and as counterpoints to the processes of commercialization and de-politicization through radio's "unique features of ownership and programming which provide for management, membership, and content to be generated by the community while simultaneously meeting its needs" (Gaynor \& O'Brien, 2010, p. 4).

\section{Community Radio and Political Awareness}


As noted above, advocates of community radio point to its capacity to stimulate information acquisition or create political awareness as a major contribution to community development (Gaynor \& O'Brien, 2011). Studies show that political awareness is a critical predictor of mass attitude change (see Zaller, 1989). Political awareness is also a requisite to citizens' political attitude and participatory behaviour. Therefore, political awareness is critical because effective democratic governance depends on the existence of an informed electorate. Popular contributions to government will be vacuous if citizens lack the knowledge or understanding of the policy debates. According to Feldman (1989), citizens who are more politically aware are likely to develop stable attitudes on major political issues, while other studies suggest that better-informed persons are more likely to demonstrate political tolerance and be supportive of government actions (Gamson \& Modigliani, 1966; Key, 1961).

In this study, engagement with community radio is operationalised in terms of participation in the medium's political talk forum (i.e., active participation in political talk show). Political talk programs are the flagship genre of political learning on community radio. They are produced in local languages, and have become popular in several African countries (Mwesige, 2009; Tettey, 2011). Since community radio is about giving voice to the voiceless, it begins with talk: talk about the everyday issues shared among community members, talk about the decisions and actions giving rise to these issues, and talk about how to tackle the issues and whose responsibility it is to do so.

Studies show that audiences regard certain new media forms especially call-in shows, and the internet as useful and valuable to civic life (Bucy, D'Angelo, \& Newhagen, 1999). With new technology fundamentally changing how users interact with media, contemporary radio phone-in programs depend on listeners' ability to become contributors through their telephones. Mwesige (2009) describes political talk as a forum for robust political debates, for finding solutions and determining development inputs that truly meet local needs. According to Mwesige, live exchanges on talk programs opens new opportunities for citizens to directly engage public officials in unique ways that traditional power relations seldom allow. Thus, political talk shows offer audiences a chance to speak and be heard "at a time when there continues to be much to say about politics, economy, and everyday struggles" (Matza, 2009, p. 489).

Although some have criticized political talk shows as "irreverent, often directing citizen anger at ruling establishments, their political opposition, or at each other" (Mwesige, 2009, p. 221), there is some degree of agreement among experts that radio talk shows influence perceptions of political efficacy (Hofstetter, et al., 1994; Hofstetter \& Gianos, 1997; Hollander, 1995a, 1995b, 1996). The programs connect citizens and their government, thereby providing a means of political 
discussion (Katz, 1992; Verba, Schlozman, Brady \& Nie, 1993). Zerbonus (1993) found that talk radio listeners are politically more attuned than non-listeners, and Hollander (1995) suggests that listening to talk shows may increase a person's perception of both competences: belief of government representatives and actual participation in the system. In other words, how effective one feels is a determinant of one's participation in the polity (Wollman \& Stouder, 1991). Mwesige (2009) describes how talk radio in Uganda serves democratic purposes, noting that participants focus on common issues of interest rather than advancing personal causes. Similarly, in a study of talk radio programs in Ghana, Tettey (2011) surmised that "participation reflects active agency, which is a critical requirement for the growth, consolidation and sustenance of democracy" (p. 21). Hence, when government officials take part in live discussions, they're careful and respectful of citizens' views (even if privately they disagree) because of the political repercussions that could follow what might be perceived as a negative reaction (Mwesige, 2009). Therefore, political talk show on community radio is one indicator of how far Africa has come in opening its airwaves for accessible discussion of issues that concern citizens. It is pertinent to focus on community radio because similar programs rarely air on public or private stations. As O'Sullivan (2005) states, "these fora allow the audience a presence, and so create at least an illusion of access to the mass media" (p. 719) which is not an insignificant starting point for citizens' understanding of politics and their engagement with the public sphere. Thus, the first set of questions asks:

$R Q 1:$ Is participation in political talk shows on community radio related to political efficacy?

$R Q 2:$ Is participation in political talk shows on community radio related to political participation?

Studies have shown that individuals who rely on the news media for information and talk about the news content with others, will have a better understanding of issues (cf. Chaffee \& Frank, 1996). Hence, this study anticipates that interpersonal discussion of issues discussed on political talk radio programs will heighten political interest and/or participation in public policy discussions. Notably, previous studies mainly focused on the effects of hard news, but not on talk program (cf. McLeod, et al., 1996; Scheufele, 2000). Political talk on radio is different from hard news in that it consists mainly of individuals' personal opinions on issues. Because radio is the most available and pervasive medium in Africa, it is important to know how much content from public issues debate on community radio enters individuals' interpersonal discussions with others. This raises a third research question: 
RQ3: Does participation in political talk shows on community radio influence an individual's discussion of local issues with others?

\section{Methodology}

\section{Study Site and Sampling Method}

The data analyzed for this study were gathered from four community radio stations in Tanzania (Sengerema FM, Afya FM, Sibuka FM, and Saut FM). The selection of stations was based on the mix of stations--private, public, and community--operating in the Lake Zone regions (Mwanza and Siriyu), permitting analysis of participants' media use. The four stations (except Afya FM) are in rural agricultural communities; hence their audiences are composed largely of farmers, fishermen, and small-scale business owners. Afya FM, a special interest station is in Mwanza city centre, but its signal reach other locations in the region. The station promotes itself as "health learning media." The Tanzania Episcopal Conference owns Saut FM, which is operated by mass communication students enrolled at St. Augustine University.

The population involved in this research is male and female adult community radio listeners, activists, volunteers, and workers. The stations assisted in listener recruitment by broadcasting announcements related to the study during their half-hourly news bulletin for two consecutive days. The publicity clearly stated the purpose of the study and provided the demographic requirements necessary to participate (e.g., regular listenership, age). Survey questionnaires were completed by interested participants at the stations. This approach was taken because studying radio audiences is a methodologically complex process; rarely can a station's audience be observed directly in radio research (Crisell,2006). Suffice to say that the primary focus of research in community communication is the individual as a member of a specific community (Hollander \& Strappers, 1992; Hollander, et al., 2002). Unlike public radio, community radio is meant to serve specific communities with individuals whose issues are aligned; people listen or are involved with the medium because of shared interests. However, participant recruitment was conducted without regard to ethnicity or gender.

Of the 400 questionnaires distributed, 307 were returned (less than $5 \%$ of potential subjects were eliminated because of their inability to complete the survey in English). This resulted in a completion rate of $76.8 \%$. The respondents ranged in age from 18 to $66(M=27.08) ; 58.6 \%$ (180) were males, and 38.8\% (119) were females. 


\section{Measures}

Many of the variables used to characterize audiences were drawn from existing verified survey items designed to measure exposure to news and public affairs in mass media communication associated with political participation. For mass media use (in line with Pan \& Kosicki's (1997) approach), the exposure items examined were measured on a four-point scale: (1=never, $2=$ hardly ever; $3=$ sometimes, $4=$ regularly, as an additive index (Cronbach's alpha $=.75)$. Activities included are: read a daily newspaper, read a magazine, watch television news (local and national), listen to radio news (local and national). A follow up question asks: "What primary purpose does the medium that you selected serve in your daily routine"? For example, I watch television because...." To measure intensity of radio use, respondents were asked, "How much time per week do you spend listening to radio? The measure, on a 6point scale, included 1=0-6.9 hours per week, $2=7-13.9$ hours per week, $3=14-20.9$ hours per week, $4=21-27.9$ hours per week, $5=28-34.9$ hours per week, 6=more than 35 hours (McNair, 2013). For the measure of engagement with community radio, respondents were asked to rank their levels of involvement with their community station on a four-point scale $(1=$ not involved, $2=$ slightly involved $3=$ moderately involved, and $4=$ very involved). Following Pan and Kosicki (1997), the measure of exposure to political talk radio was differentiated from other media use, because talk radio is construed as a type of opinion activity and not a mere media exposure (Crittenden, 1971). To measure this exposure, respondents were asked: "How often, if ever, do you listen to radio shows that invite listeners to call-in or send a text message to discuss current events, public issues, and politics: 1=never, $2=$ =ery rarely, 3=rarely, 4=occasionally, 5=very frequently, 6=always?" Respondents who said "never" were coded as "non-listeners". A follow up question asks: "Have you, yourself ever tried to call into such a radio program, or not?" Respondents replying "yes" were coded as "callers" and those answering "no" as "listeners." Following Scheufele's (2002) study on differential gains, frequency of interpersonal discussion about politics was measured using a two-item composite $(\alpha=.53)$ of discussion of local and national politics. Respondents were asked: "How often do you discuss things happening in your community with neighbours or friends?" and "How often do you discuss national affairs with others?" Responses were measured on a five-point scale 1=never, $2=$ less than once a week, $3=$ once or twice a week, $4=$ nearly every day, 5=every day.

Measure of political variables. The scale used to measure interest in local and national politics, drawn from Scheufele (2002), is a combined additive index $(a=.63)$. The question asks, "Thinking about your local community, how interested are you in local community politics and local community affairs?" The second question asks, "How interested are you in national politics and national affairs?" Response options on a five-point scale include, 1=not interested, $2=$ slightly 
interested, 3=somewhat interested, $4=$ very interested, and 5=extremely interested.

The questionnaire included 6 out of 14-16 conventional nonvoting items traditionally used to measure participation politics. Respondents were asked to answer "yes" or "no" to any of the activities which includes attending neighbourhood meetings, writing letters to an elected official or the news media, or calling to a radio station. The six items selected were considered relevant to political activities in subSaharan Africa. The six-participatory behaviour were combined into an additive index, and the analysis revealed adequate internal consistency $(a=.65)$. The items were adopted from previous studies (Hofstetter \& Gianos, 1997; Hollander, 1995, 1996; McLeod, et al., 1999).

The questionnaire provided three items, each intended to differentiate the two efficacy dimensions-internal (self) and external (system). For "self-efficacy", the following statements were presented: "I consider myself well-qualified to participate in politics"; "I feel that I have a pretty good understanding of the important political issues facing my country"; "I feel that I could do as good a job in public office as most other people". Responses range on a five-point scale from "strongly agree" to "strongly disagree". System efficacy was similarly measured in response to the following statements: "Under our form of government, the people have the final say about how the country is run, no matter who is in office"; "If public officials are not interested in hearing what the people think, there is really no way to make them listen"; "There are many legal ways for citizens to successfully influence what the government does" were presented.

\section{Analytical Method}

The research questions in this study specifically sought expectations about possible association between participation in political talk on community radio and political participation and efficacy. Previous studies on talk radio consistently provides bivariate relationship to explain both the predictors of listening and to describe relevant variables of merest.

\section{Results}

\section{Frequencies}

The media use variables show that radio programming is an extremely popular medium in Tanzania. The mean number of hours spent weekly listening to radio is greater $(M=3.57, S D=.61)$ than for other media types (Table 1). For exposure to talk shows, the mean score is $4.50(S D=1.51)$ on a $1-6$ scale. Only $6.6 \%$ of respondents $(20$ of 305) indicated that they'd never listened to a political talk radio program. Of the remaining 285 respondents who listen, 199 are callers $(69.8 \%)$ while 106 are merely listens without making calls (37.2\%). Only $(62.1 \%)$ of the sample are call frequently or always (Table 2). The data support the 
differentiation made between listeners and callers, and as expected, callers are more frequent listeners than listeners who do not make calls.

Table 1: Media Use Statistics

\begin{tabular}{lccl}
\hline & $\mathrm{N}$ & Mean & Std. Deviation \\
\hline Newspaper & 300 & 3.05 & 0.728 \\
TV National news & 299 & 3.26 & 0.865 \\
Magazine & 296 & 2.97 & 0.875 \\
TV Local News & 298 & 3.26 & 0.891 \\
Radio News & 300 & 3.57 & 0.605 \\
\hline Valid N (listwise) & 288 & & \\
\hline
\end{tabular}

Table 2: Levels of Talk Show Exposure

\begin{tabular}{lll}
\hline & Frequency & Percentage \\
\hline Never & 20 & 6.6 \\
Very rarely & 16 & 5.2 \\
Rarely & 38 & 12.5 \\
Occasionally & 54 & 17.7 \\
Very frequently & 71 & 23.1 \\
Always & 106 & 34.8 \\
\hline Total & 305 & 100 \\
\hline
\end{tabular}

\section{Bivariate relationships}

For the first research question that asked: "Is participation in political talk show on community radio related to political efficacy?", a Pearson correlation coefficient was calculated to determine whether a relationship exists between callers and political efficacy. A positive but weak correlation was found $(r(288)=.153, p<.01)$ for external efficacy including a significant linear relationship between the two variables (Table 3). The results suggest possible confidence for government officials, pointing to improved democracy. The mean score of system efficacy was $(M=9.66, S D=2.36[n=288])$. A vote of confidence for government executives indicate their responsiveness as part of the healthy function of the system of representative democracy. However, previous studies suggest that external efficacy is more susceptible to situation factors. In other words, system efficacy is susceptible to change 
depending on the situation, therefore, talk radio may have greater interest on it, but in opposite direction. However, the result showed no correlation for self-efficacy $(r(286)=.088, p>.05)$. The mean score for self-efficacy was $(M=10.65, S D=2.01[\mathrm{n}=288])$. This is not a surprise, in that previous studies have shown self-efficacy to be stable within individuals with the possibility of being enhanced by political discussion on radio (Hollander, 1995). Table 3 shows that mere listening and not participating in the program is not correlated in any form to the two efficacy dimensions.

To answer RQ2, "Is participation in political talk on community radio associated with political participation?", the Pearson correlation coefficient showed a significant positive correlation between active engagement with political talk show and political participation $(r(260)=$ $.271, p$ <.001) (see Table 3.). This indicates that a correlation exists between engagement with political talk shows and political participation, but the association is weak. Individuals who are highly involved with talk programs are more likely than others to have knowledge of political issues and be involved in local political affairs. The results also show a similar positive linear relationship between participation in political talk program and political interest $(r$ (295) $=$ .208, $p<.001)$ suggesting that those who participate in political talk shows tend to be interested in politics, and they might just be using the program both to sharpen their political knowledge, and to promote personal political interest.

Table 3: Correlation among selected variables

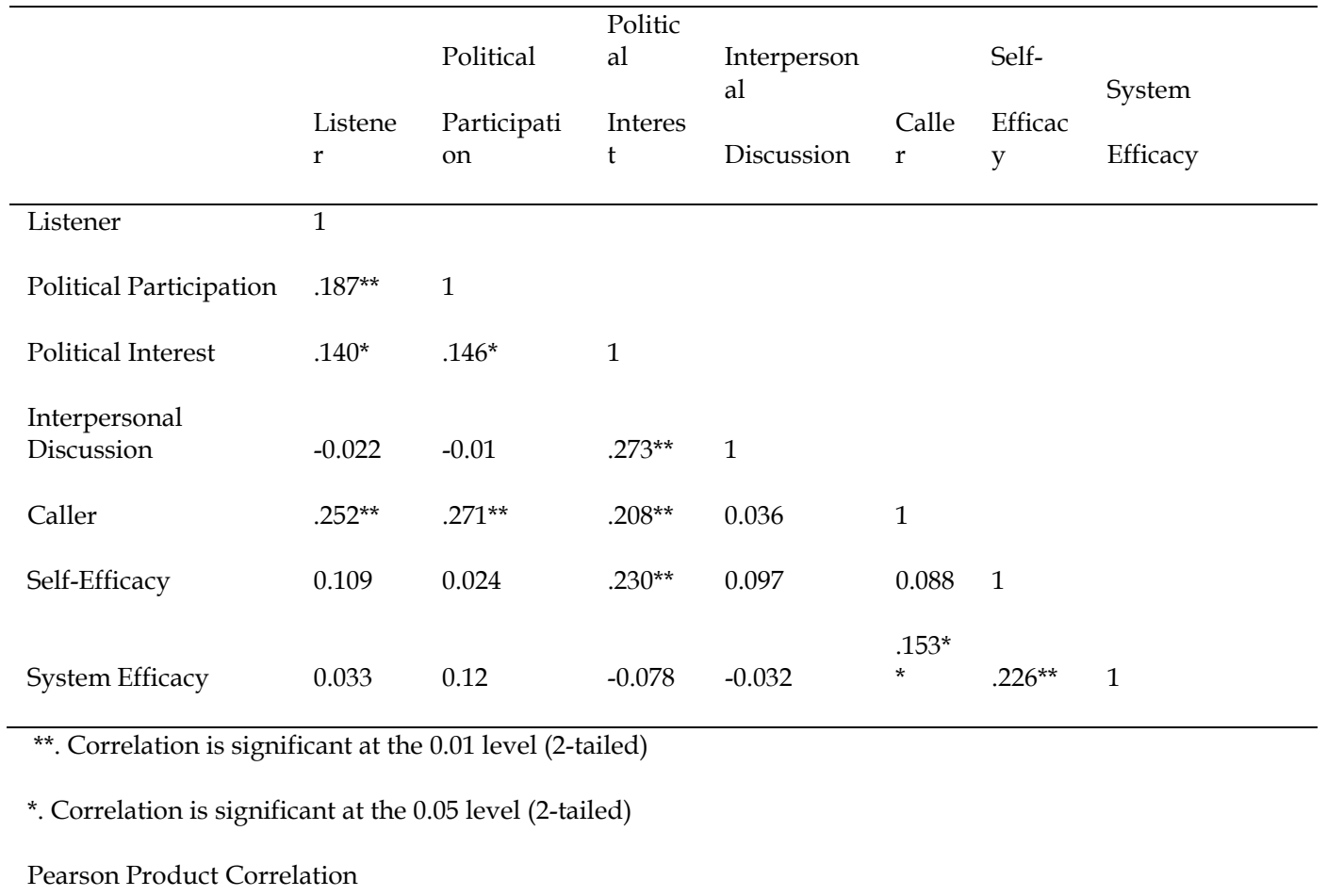


Finally, to answer RQ3, "Is participation on political talk on community radio related to individual's interpersonal discussion of local issues?" Pearson correlation was calculated to examine the relationship between the two variables. The result shows a weak correlation that was not significant $(r(298)=.036, p>.05)$; participation is not related to interpersonal discussion.

\section{Conclusions}

The emergence of community radio on the media landscape of Tanzania has introduced a new information sharing dynamic with potentials for social change. Evidence available from this study suggest a willing desire by the stations to fulfil an important role of providing communities with timely information about the world. At the same time, citizens are expressing optimism about access to a larger polity made available to them by the stations. Although the stations work to produce a wide diversity of locally produced programs to meet community expectations, the political talk-back program is the most significant program on air. Audiences interviewed claim it is one of the major reasons they listen. For those that participate, they see talk-back forum as opportunity to inject their views and ideas and potentially influence the polity. Interestingly, our visit for this research coincided with the period Tanzanians were debating two major national issues: a constitutional reform, and the election of new government. Participation on the issues across the four community stations were vigorous. Also, openly debated on the airwaves were issues such as gender inequality, ritual killings of albinos, and "nyumba ntobo" - a practice that forces a young girl to "marry" a widowed woman to bear a son for inheritance purposes. These issues hitherto had not seen daylight or received media attention, because they fall under local customs, and are treated as taboos. Arguably, the stations are "forcing" a change in the system.

Across the stations, pervasive call-in programs provide an excellent, unstructured outlet for public discourse. The convergence of radio with the new technologies is ably aiding citizens' participation in on-air political discussions. In fact, new technologies (such as SMS) have enhanced community radio's performance as a public sphere infrastructure. The popularity of political talk radio is greatly aided by use of text messaging. In effect, more people join to articulate their autonomous views towards influencing the political institutions of society. In this way, community radio is playing an important cultural role of encouraging dialogue between diverse components of a community, a process that is integral to community social structure. The talk-back programs illuminate debates about the nature of the public sphere, that is, its universal access and its potential as a platform for opinion formation. To this extent, a new media audience is emerging, one that is non-passive, but is participative and independent. Thus, we've realized through media interconnection, a vision that was once only imagined. 
This study revealed a significant positive association between participation in political talk program and system efficacy, a finding that suggests that community radio tends to promote political interest and political participation. Most importantly, our research revealed evidence that community radio could impact political discourse and political learning. Thus, engagement with community radio is serving a useful democratic function of empowering citizens, clearly giving credence to the notion that political discourse is at the heart of democracy (de tocqueville's,1835/1984). We surmise, therefore, that the community radio sector is strategically helping to forge a democratic society by giving citizens the opportunity to communicate their thoughts and actions to others around them. Without doubt, the model's organizational structures encourage active citizen participation and a healthy diversity of opinion. Thus, the sector is meeting the atypical expectation of public radio service - informing citizens at the local levels, and at the same time giving voice to their views. In so doing, community radio in Tanzania is filling the void left for decades by commercial and public broadcasting services. The mere fact that information is regularly available to citizens gives us confidence that the root for enlightenment is being planted at the local levels. This form of communication must take place if sustainable democratic development is to occur. Most significantly, the presence of this sector in rural communities appears to have widened the boundaries of citizens' awareness.

Nonetheless, major challenges remain that threaten community radio's viability as public sphere in Africa. First is financial solvency. Generally, financial sustenance is a common problem with community stations because by their very nature, they should rely on local resources. However, this problem is more acute in Africa given the small-scale economies of the rural communities. The support from listeners, the primary source, is paltry, if at all it exists. Thus, the stations struggle to stay afloat, and are forced to look to advertising or support from government or international development agencies to maintain their services. The temptation is strong to embrace commercial support for the sake of sustainability. Not surprisingly, we witnessed evidence of this drift as the stations we visited used the flavour of local music (or entertainment) to attract audiences' attention to their niche. This is understandable given the fact that they're competing with commercial stations for audience's attention. The danger however, is that the drift towards entertainment content for commercial reasons could make them lose the character of public sphere.

A final point to consider is the issue of (in)tolerance of differing viewpoints by African leaders. Without doubt, tolerance is essential to a functional democracy. Although the number of African countries with freedom of information laws (or right to information) has increased over the years, but providing the public with information about how government works or policy details is another issue. Of course, related to 
this is the question of how long African leaders are willing to tolerate differing opinion. So, non-compliance with freedom of information and leadership intolerance could potentially stifle the role that community radio can play in Africa. For now, however, it is sufficient to recognize that community radio could lead the vanguard for larger social movement to democratize society by heightening the level of citizen participation. The opportunity to provide space for people to come together to freely discuss and identify societal problems, and through that discussion bring about social change, is a major reason many point to community radio as a public sphere.

\section{Acknowledgement}

Funding for this research was made possible by the Thomas Jay Harris Institute for Hispanic and International Communication in Texas Tech University's College of Media and Communications.

\section{References}

Abramson, Paul. R., and John H. Aldrich. (1982).

The decline of electoral participation in America. American Political Science Review, 76(03), pp. 502-521.

Article XIX. (2003).

Broadcasting policy and practice in Africa. London: Article 19.

Retrieved from:

http://www.article19.org/data/files/pdfs/publications/africabroadcasting-policy.pdf

Ascroft, Joseph and Sipho Masilela. (1994).

Participatory decision making in Third World development. In S. White, K. S. Nair, \& J. Ascroft (Eds.), Participatory communication: Working for change and development (pp. 259-294). New Delhi: Sage Publications.

Barlow, William. (1988).

Community radio in the US: The struggle for a democratic medium. Media, Culture E Society, 10, pp. 81-105.

BBC World Service Trust. (2006).

African media development initiative (AMDI). London: BBC Research Summary Report. Retrieved from:

http:/ / africanmediainitiative.org/content/2013/07/22/ AMDI-

BBC-summary-report.pdf

Berelson, Bernard R., Paul F. Lazarsfeld and William N. McPhee. (1954).

Voting: A study of opinion formation in a presidential campaign.

Chicago: University of Chicago Press.

Bucy, Erik. P., Paul D ‘Angelo and John E. Newhagen. (1999). 
Engaging the electorate: New media use as political participation. In L.L. Kaid \& D. G Bystrom (Eds.), The electronic election:

Perspectives on the 1996 campaign communication (pp. 335-347). Mahwah, NJ: Erlbaum

Calhoun, Craig. (Ed.). (1992).

Habermas and the public Sphere. Cambridge: The MIT Press.

Carpenter, Nico. (2011).

Media and participation: A site of ideological-democratic struggle.

Bristol, UK: Intellect Ltd.

Castells, Manuel. (2008).

The new public sphere: Global civil society, communication networks, and global governance. The Annals of the American Academy of Political and Social Science, 616(1), pp. 78-93.

Chaffee, Steven, and Stacey Frank. (1996).

How Americans get political information: Print versus broadcast news. The Annals of the American Academy of Political and Social Science, 546, pp. 48-58. DOI: 10.1177/0002716296546001005.

Crisell, Andrew. (2006). Understanding radio. London: Routledge

Crittenden, John. (1971).

Democratic functions of the open mike radio forum. Public Opinion Quarterly 35, pp. 200-210.

Da Costa, Peter. (2012).

The growing pains of community radio in Africa: Emerging lessons towards sustainability. Nordicom Review, 33, pp.135-148.

Dahlgren, Peter. (1995).

Television and the public sphere: Citizenship, democracy, and the media. London: Sage.

Day, Rachel. (2009).

Community radio in Ireland: Participation and multiflows of communication. Cresskill, New Jersey: Hampton Press.

Deane, James. (2005).

Media, democracy, and the public sphere. In O. Hemer \& T.Tufte (Eds.). Media and global change: Rethinking communication for development (pp. 177-192). Buenos Aires: Nordicom.

de Tocqueville, A. (1984).

Democracy in America. New York: Penguin Books. (Original work published 1835)

Downing, John D. H. (2001).

Radical media: Rebellious communication and social movements.

Thousand Oaks, CA: Sage.

Fairchild, Charles. (2001).

Community radio and public culture: Being an examination of media access and equity in the nations of North America. Cresskill, N.J:

Hampton Press.

Feldman, Stanley. (1989). 
Reliability and stability of policy positions: Evidence from a fivewave panel. Political Analysis, 1. pp. 25-60

Forde, Susan, Kerrie Foxwell, and Michael Meadows. (2002).

Creating a community public sphere: Community radio as a cultural resource. Media International Australia incorporating culture and policy, 103(1), pp. 56-67.

Gamson, William and Andre Modigliani. (1966).

Knowledge and foreign policy opinions: Some models for consideration. Public Opinion Quarterly, 30, pp. 187-199.

Gaynor, Namh and Anne O'Brien. (2010).

Drivers of change? Community radio in Ireland. Retrieved from:

http:/ / doras.dcu.ie/16219/1/PDF_FinalReport.pdf

Gaynor, Namh and Anne O'Brien. (2011).

Community radio in Ireland: Defeudalising the public sphere?

Javnost-The Public, 18(3), pp. 23-37.

Habermas, Jürgen. (1989).

The structural transformation of the public sphere: An enquiry into a category of bourgeois society. Cambridge, Mass: MIT Press.

Habermas, Jürgen, Lennox, Sara and Lennox, Frank. (1974).

The public sphere: An encyclopaedia article (1964). New German Critique, (3), pp. 49-55.

Hofstetter, C. Richard, Mark C. Donovan, Melville R. Klauber, Alexander Cole, Carolyn J. Huie, and Toshiyuki Yuasa. (1994). Political talk radio: A stereotype reconsidered. Political Research Quarterly, 47(2), pp. 467-479.

Hofstetter, C. Richard, and Christopher L. Gianos. (1997).

Political talk radio: Actions speak louder than words. Journal of Broadcasting E Electronic Media, 41(4), pp. 501-515.

Hollander, Barry. A. (1995a).

The influence of talk radio on political efficacy and participation. The Journal of Radio Studies, 3, pp. 23-31

Hollander, Barry. A. (1995b).

The new news and the 1992 presidential campaign: Perceived vs. actual political knowledge. Journalism \& Mass Communication Quarterly, 72(4), pp. 786-798.

Hollander, Barry. A. (1996).

Talk radio: Predictors of use and effects on attitudes about government. Journalism \& Mass Communication Quarterly, 73(1), pp. 102-113.

Hollander, Ed. (2002).

Community media and online communities: Towards a theoretical and methodological framework. In N. Jankowski, \& O. Prehn (Eds.), Community media in the information age: Perspectives and prospects (pp. 19-30). Cresskill, NJ: Hampton Press.

Hollander, Ed., and James Stappers. (1992). 
Community media and community communications. In $\mathrm{N}$. Jankowski, O. Prehn, J. Stappers (Eds.), The people's voice: Local radio and television in Europe (pp. 17-27). London: John Libby.

Hollander, Ed, James Stappers, and Nicholas Jankowski. (2002). Community media and community communication. In $\mathrm{N}$. Jankowski, \& O. Prehn (Eds.), Community media in the information age: Perspectives and prospects (pp. 31-46). Cresskill, NJ: Hampton Press.

InterMedia.org. (2011).

AudienceScape: Development Research Report. Tanzanian media environment: Current access, potential for growth and strategies for information dissemination. Retrieved from:

http:/ / www.intermedia.org/wp-content/uploads/TanzaniaMedia-Environment_0.pdf

Jallov, Brigitte. (2007).

Community radio in East Africa: An impact and sustainability assessment of three community radios within the EACMP.

Commissioned by SIDA Department for Democracy and Social

Development. Birgitte Jallow Communication Partners.

Jankowski, Nicholas. W. (2003).

Community media research: A quest for theoretically grounded models. Javnost - The Public 10 (1), pp. 5-15.

Jankowski, Nicholas., Ole Prehn and James Stappers. (Eds.). (1992).

The people's voice: Local radio and television in Europe (Vol. 6).

London: J. Libbey.

Katz, Leavy. J. (1992, March 5).

Rock, rap and movies bring you the news. Rolling Stone, 25, 33-37.

Kellner, Douglas. (2000).

Habermas, the public sphere, and democracy: A critical

intervention. Perspectives on Habermas, pp. 259-288.

Key, Valdimar Orlando. (1961).

Public opinion and American democracy. New York: Knopf.

Lazersfeld, Paul F., Berelson, Bernard. R, and Hazel Gaudet. (1944).

The people's choice. New York: Columbia Univ. Press.

Louw, Eric. (2001).

The media and cultural production. London: Sage.

McLeod, Jack M., Katie Daily, Zhongshi Guo, William P. Eveland Jr, Jan

Bayer, Seungchan Yang, and Hsu Wang. (1996). Community

integration, local media use, and democratic processes.

Communication Research, 23(2), 179-209.

McNair Ingenuity (2013).

Community broadcasting audience survey. Retrieved from:

http:/ / www.cbonline.org.au/index.cfm?pageId=44,184,3,2062

Meadows, Michael, Susan Forde, Jacqui Ewart, and Kerrie Foxwell.

(2005). 
Creating an Australian community public sphere: The role of community radio. Radio Journal: International Studies in Broadcast $\mathcal{E}$ Audio Media, 3(3), 171-187. doi: 10.1386/rajo.3.3.171_1

Melkote, Srinivas R. (2002).

Theories of development communication. In Gudykurst, W. B. \& Mody. B. (Eds.), Handbook of international and intercultural communication, (2nd edition, pp. 419-436). Thousand Oaks, CA: Sage.

Matza, Tomas. (2009).

Moscow's echo: Technologies of the self, publics, and politics on the Russian talk show. Cultural Anthropology, 24(3), pp. 489-522.

Mwesige, Peter G. (2009).

The democratic functions and dysfunctions of political talk radio: the case of Uganda. Journal of African Media Studies, 1(2), pp. 221245.

O'Sullivan, Sara. (2005).

The whole nation is listening to you: The presentation of the self on a tabloid talk radio show. Media, Culture $\mathcal{E}$ Society, 27(5), pp. 719-738.

Pan, Zhongdang, and Gerald M. Kosicki. (1997).

Talk show exposure as an opinion activity. Political Communication, 14(3), 371-388.

Panos Institute West Africa. (2011).

The African charter on broadcasting: A review of its impact in West Africa. Retrieved from:

http:/ / panosnetwork.org/attachments/article/140/Panos_Chart _An.pdf

Rosenstone, Steven, and John M. Hansen. (1993).

Mobilization, participation, and democracy in America. New York:

Macmillan.

Scheufele, Dietram. A. (2002).

Examining differential gains from mass media and their

implications for participatory behavior. Communication Research, 29(1), pp. 46-65.

Sen, Amartya. (2001).

Development as freedom. New York: Knopf.

Servaes, Jan, and Patchanee Malikhao. (2008).

Development communication approaches in an international perspective. In J. Servaes, (Ed.), Communication for development and social change (pp. 158-179). New Delhi: Sage.

Stamm, Keith R. (1985).

Newspaper use and community ties: Towards a dynamic theory.

Norwood, NJ: Ablex Publishing Corporation.

Tettey, Wisdom J. (2011).

Talk radio and politics in Ghana: Exploring civic and (un)civic discourses in the public sphere. In L. Gunner, D. Lagaga, \& D. 
Moyo (Eds.), Radio in Africa: Politics, culture, communities (pp. 1936). Johannesburg: WITS University.

Tucker, Ericka. (2013).

Community radio in political theory and development practice. Journal of Development and Communication Studies, 2, pp. 392-420.

Verba, Sidney, Kay Lehman Schlozman, Henry Brady, and Norman H. Nie. (1993). Citizen activity: Who participates? What do they say? American Political Science Review, pp. 303-318.

Viswanath, Kasisomayajula, John R. Finnegan Jr, Brenda Rooney Jr, and John Potter Jr. (1990). Community ties in a rural Midwest community and use of newspapers and cable television. Journalism Quarterly 67(4). pp.899-911.

Wollman, Neil and Stouder, Robin. (1991).

Believed efficacy and political activity. A test of the specificity hypothesis. The Journal of Social Psychology, 131(4), pp. 557-566

Zaller, John. (1987).

Diffusion of political attitudes. Journal of Personality and Social Psychology, 53(5), p. 821=833.

Zaller, John. (1989).

Bringing converse back in: Modeling information flow in political campaigns. Political analysis, 1, pp. 181-234.

Zerbinos, Eugenia. (1993).

Talk Radio: Motivation or titillation? (paper presented at the annual meeting of AEJMC, Kansas City 